Natural Hazards and Earth System Sciences (2003) 3: 367-376

(C) European Geosciences Union 2003

Natural Hazards
and Earth
System Sciences

\title{
The 1867 Virgin Island Tsunami
}

\author{
N. Zahibo ${ }^{1}$, E. Pelinovsky ${ }^{2}$, A. C. Yalciner ${ }^{3}$, A. Kurkin ${ }^{4}$, A. Koselkov ${ }^{4}$, and A. Zaitsev ${ }^{4}$ \\ ${ }^{1}$ Laboratoire de Physique Atmosphérique et Tropicale, Département de Physique, Université Antilles Guyane, Pointe-a-Pitre, \\ France \\ ${ }^{2}$ Laboratory of Hydrophysics and Nonlinear Acoustics, Institute of Applied Physics, Nizhny, Novgorod, Russia \\ ${ }^{3}$ Civil Engineering Department, Ocean Engineering Research Center, Middle East Technical University, Ankara, Turkey \\ ${ }^{4}$ Applied Mathematics Department, Nizhny Novgorod State Technical University, Nizhny Novgorod, Russia
}

Received: 7 October 2002 - Revised: 5 February 2003 - Accepted: 7 February 2003

\begin{abstract}
The 1867 Virgin Island Tsunami reached large magnitude on the coasts of the Caribbean Islands. A maximum tsunami height of $10 \mathrm{~m}$ was reported for two coastal locations (Deshaies and Sainte-Rose) in Guadeloupe. Modelling of the 1867 tsunami is performed in the framework of the nonlinear shallow-water theory. The directivity of the tsunami wave source in the Caribbean Sea according to the assumed initial waveform is investigated. The tsunami records at the several coastal regions in the Lesser Antilles, Virgin Islands, Puerto Rico and South America are simulated. The comparison between the computed and observed data is in reasonable agreement.
\end{abstract}

\section{Introduction}

In order to understand and discuss tsunami danger for the coastal region of the Caribbean Islands, including the Lesser Antilles, the investigation of historical tsunami events, appropriate numerical modeling, and comparison of model results with the existing information are necessary and effective tools. Based on historical information, a total of 23 tsunami-like waves were reported in the Lesser Antilles over the last 400 years. Among them 16 events are of seismic origin, 4 events are of volcanic origin and 3 events are of unknown cause (Zahibo and Pelinovsky, 2001). Recently, Lander et al. (2002) prepared a new list of tsunamis in the Caribbean Sea. In the last 35 years there were 4 true weak tsunamis: 25 December 1969 (earthquake with magnitude 7.6 in the Lesser Antilles, maximum positive tsunami amplitude of $46 \mathrm{~cm}$ at Barbados); 16 March 1985 (moderate earthquake with magnitude 6.3 in Guadeloupe, a tsunami several centimeters high was recorded at Basse Terre, Guadeloupe); 9 July 1997 (earthquake of magnitude 6.8 occurred off the coast of Venezuela induced a weak tsunami on Tobago); 26 December 1997 (volcanic eruption in Montserrat generated a wave with a height of $3 \mathrm{~m}$ at Old Road Bay). Many historical

Correspondence to: N. Zahibo (narcisse.zahibo@univ-ag.fr) catastrophic tsunamis are not well documented and cannot be confirmed as true tsunamis. On the basis of these data, a rough evaluation of the cumulative frequency of tsunamis was done for Barbados and Antigua (Zahibo and Pelinovsky, 2001). The accuracy of such estimates is low, and numerical simulation of the historical and prognostic tsunamis is necessary to create a more reliable tsunami database. In particular, tsunamis can be generated by volcanic eruptions. The Soufriere Hills Volcano in Montserrat erupted several times in the 90s (Hooper and Mattioli, 2001) and generated tsunami waves on 26 December 1997 with a height of 3 m. Heinrich et al. (1998, 1999a, b, 2001), studying the danger of volcanic eruption in the Soufriere Hills Volcano, Montserrat, showed that the potential debris avalanche can induce tsunami waves of 1-2 m nearby in nearest zone and 50 $\mathrm{cm}$ at Guadeloupe and Antigua. Le Friant (2001) simulated tsunami waves from potential eruption of the St. Pierre Volcano, Martinique. Recently, submarine evidence for largescale debris avalanches for many islands in the Lesser Antilles Arc was found (Deplus et al., 2001).

In addition to being subject to local tsunamis the Lesser Antilles is also a target of transoceanic tsunamis. The tsunami generated by the 1755 Lisbon Earthquake crossed the Atlantic in $7 \mathrm{~h}$ and affected several locations in the Caribbean Islands, causing runup heights of $7 \mathrm{~m}$ (Saba), $4.5 \mathrm{~m}$ (St. Martin), $3.7 \mathrm{~m}$ (Dominica), $3.7 \mathrm{~m}$ (Antigua) and $1.5 \mathrm{~m}$ (Barbados). Recently, Mader (2001a) simulated this transoceanic tsunami propagation. According to his calculations, the wave amplitude east of Saba at depth $4747 \mathrm{~m}$ is $2.5 \mathrm{~m}$, and at depth $825 \mathrm{~m}$ is $5 \mathrm{~m}$, close to the observed value $(7 \mathrm{~m})$. We would also like to mention a possible tsunami expected from a lateral collapse of the Cumbre Vieja Volcano in La Palma (Canary Islands); according to Mader (2001b) its amplitude may be $3 \mathrm{~m}$ high on the coasts of the Caribbean Islands (Saba Island). Pararas-Carayannis (2002) discussed possibility of $40 \mathrm{~m}$ waves during this event.

The tsunami of 1867 in the Caribbean Sea is welldocumented. On 18 November 1867, at approximately 02:45 LT (18:45 UT) a violent earthquake occurred at the Vir- 
Table 1. Tsunami waves reported during the 1867 event

\begin{tabular}{lll}
\hline Island & Site & $\begin{array}{l}\text { Maximum positive } \\
\text { amplitude, } \mathrm{m}\end{array}$ \\
\hline Puerto Rico & San Juan & 0.9 \\
Puerto Rico & Yabucoa Harbor & 2.0 \\
Puerto Rico & Arroyo (near Guayama) & 1.5 \\
Vieques, Puerto Rico & & high waves \\
British Virgin Islands, Tortola & Road Town & 1.5 \\
British Virgin Islands, Peter Island & & 1.5 \\
US Virgin Islands, Saint Thomas & Charlotte Amalie & 6.0 \\
US Virgin Islands, Hassel Island & & 4.9 \\
US Virgin Islands, Saint Croix & Fredericksted & 7.6 \\
Saba Island, Netherlands Antilles & & high wave \\
St. Kitts & & sea rose high \\
Antigua & St. John's & 3.0 \\
Guadeloupe & Deshaies & 10.0 \\
Guadeloupe & Sainte Rose & 10.0 \\
Guadeloupe & Basse Terre & 2.0 \\
Guadeloupe, Isles des Saintes & & 1.0 \\
Grenadines, Bequia Island & Port Elizabeth & 1.8 \\
Grenada & Gouyave & 3.0 \\
Grenada & Saint George's & 1.5 \\
Isle de Margarita, Venezuela & & reported \\
\hline
\end{tabular}

gin Islands (Fig. 1). Its surface magnitude was 7.5 and focal depth was less than $30 \mathrm{~km}$. The earthquake was strong; it had intensity 9 at the British Virgin Islands (Tortola, St. John), the US Virgin Islands (St. Thomas, St. Croix) and Puerto Rico (Viequez and Culebra). Lander et al. (2002) indicate that the earthquake occurred in Anegada Passage between Saint Croix and Saint Thomas, the US Virgin Islands. The same location, $18.0^{\circ} \mathrm{N} 65.0^{\circ} \mathrm{W}$ is given on the NOAA/NESDIS/National Geophysical Data Center web site. In ETDB/ATL (2002), the epicenter coordinates are given as $18.4^{\circ} \mathrm{N} 64.3^{\circ} \mathrm{W}$. This location corresponds to the British Virgin Islands, near Virgin Gorda, east of Tortola. In fact, both locations are along the axis of Anegada Passage, inclined by 300 to the local latitude. This deepest passage $(4500 \mathrm{~m}$ maximum depth) has a minimum width of $56 \mathrm{~km}$. Reid and Taber (1920) concluded that the length of the source was a few tens of kilometers, while the vertical displacement of the sea floor was less than ten meters; the strike of the fault must have been approximately east-west, following the general direction of the scarp. They also mentioned that according to the observers there were two severe shocks separated by an interval of about 10 minutes, and each of these shocks was followed by a great sea wave.

Tsunami waves, generated at the Virgin Islands on 18 November 1867, were significant in Puerto Rico (up to $2 \mathrm{~m}$ runup), the Virgin Islands (up to $9 \mathrm{~m}$ runup on St. Croix), the Lesser Antilles (Antigua, Netherland Antilles, St. Kitts, Guadeloupe, Grenadines, Grenada), and Venezuela (Isla de Margarita). The wave height exceeded $10 \mathrm{~m}$ at Guadeloupe and this is the highest reported value of tsunami height in the Caribbean Sea (Lander et al., 2002). Historical evidence of this event is presented in Reid and Taber (1920), Lander et al. (2002), and Zahibo and Pelinovsky (2001). Tsunami observations are given in Table 1 and presented in Fig. $1 . \mathrm{Nu}-$ merical simulation of the 1867 event and comparison with the observed data is the main goal of this paper. A numerical model based on shallow-water theory is briefly described in Sect. 2. The propagation of the tsunami and its directivity according to the selected source are computed (Sect. 3). The time histories of water surface fluctuations at selected locations are also calculated and compared with the available observations.

\section{Mathematical model}

The shallow water theory in Cartesian coordinates, with Coriolis effect omitted, is used for simulating the long wave propagation. The governing equations are,

$$
\begin{aligned}
& \frac{\partial M}{\partial t}+\frac{\partial}{\partial x}\left(\frac{M^{2}}{D}\right)+\frac{\partial}{\partial y}\left(\frac{M N}{D}\right)+ \\
& g D \frac{\partial \eta}{\partial x}+\frac{k}{2 g D^{2}} M \sqrt{M^{2}+N^{2}}=0 \\
& \frac{\partial N}{\partial t}+\frac{\partial}{\partial x}\left(\frac{M N}{D}\right)+\frac{\partial}{\partial y}\left(\frac{N^{2}}{D}\right)+ \\
& g D \frac{\partial \eta}{\partial y}+\frac{k}{2 g D^{2}} N \sqrt{M^{2}+N^{2}}=0 \\
& \frac{\partial \eta}{\partial t}+\frac{\partial M}{\partial x}+\frac{\partial N}{\partial y}=0
\end{aligned}
$$




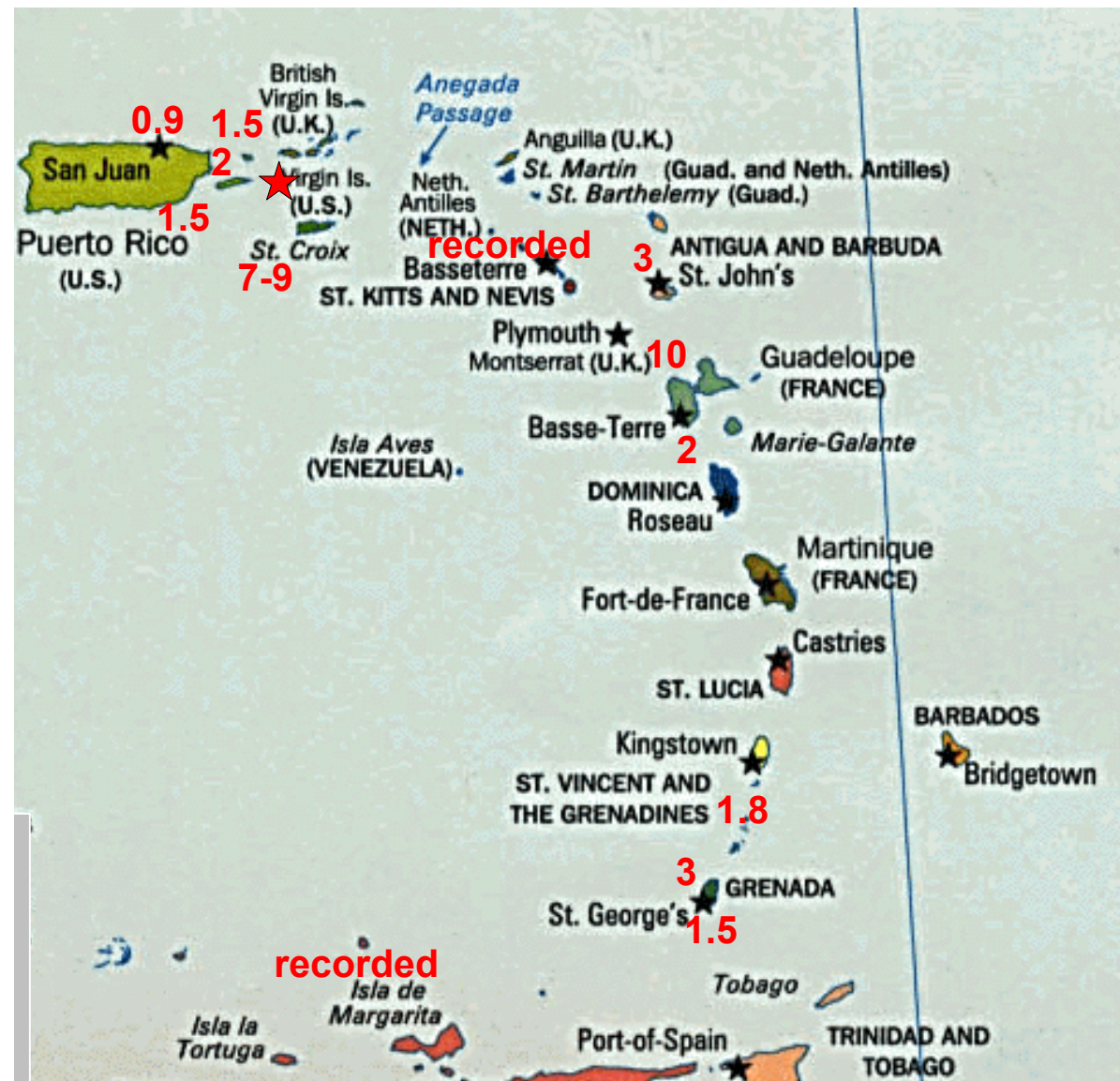

Fig. 1. Observed runup amplitudes (m) during the 1867 tsunami.

where $\eta$ is the water surface elevation, $t$ is time, $x$ and $y$ are the horizontal coordinates in zonal and meridional directions, $M$ and $N$ are the discharge fluxes in the horizontal plane along $x$ and $y$ coordinates, $D=h(x, y)+\eta$ is the total water depth, $h(x, y)$ is the undisturbed basin depth, $g$ is the gravity acceleration and $k$ is the bottom friction coefficient. The effect of the bottom friction coefficient on the attenuation of long waves has been examined by Doganay (1997) and Fujima et al. (2002). A general value of 0.025 recommended by Prof. Imamura is used as the bottom friction coefficient in this application. In the numerical simulation, the tsunami propagation model TUNAMI-N2 is used. This model was developed in the Tohoku University (Japan) and provided to the tsunami community through the Tsunami Inundation Modeling Exchange (TIME) program (Goto el al., 1997). It has been applied to several case studies for Puerto Rico (Mercado and McCann, 1998) and Turkey (Yalciner et. al., 2002). The model solves the governing equations by the finite difference technique with leap-frog scheme (Goto et al., 1997). The bathymetry of the Caribbean Sea was obtained from the Smith and Sandwell global seafloor topography (ETOPO2) with a $3-\mathrm{km}$ grid size. The total number of grid points in the study area is $433580(815 \times 532)$. The time step is selected as $6 \mathrm{~s}$ to satisfy the stability condition. Free outward passage of the wave is permitted at the open sea boundaries. The program can compute the wave propagation at all locations, even at shallow and land regions (Imamura, 1996) within the limitations of grid size.

The earthquake epicenter is assumed to be located at the site with coordinates: $18.0^{\circ} \mathrm{N} 65.0^{\circ} \mathrm{W}$ according to the data of NOAA/NESDIS/National Geophysical Data Center (see Fig. 1). The surface magnitude of the tsunamigenic earthquake is chosen as 7.5 according to ETDB/ATL (2002). The length of the fault is $120 \mathrm{~km}$ and the width is $30 \mathrm{~km}$. Reid and Taber (1920) suggested that the fault is oriented from west to east. By using this information, the fault line (axis of the initial form of the tsunami wave) is assumed to be situated between the coordinates $65.66^{\circ} \mathrm{W}, 18.00^{\circ} \mathrm{N}$ and $64.36^{\circ} \mathrm{W}$, $18.00^{\circ} \mathrm{N}$. Since there is no sufficient information available about the source parameters of the earthquake, the dip and slip angles of the fault are selected as $70^{\circ}$ and $90^{\circ}$, respectively. The displacement and focal depth have been selected as $8 \mathrm{~m}$ and $3000 \mathrm{~m}$. The initial wave is computed according to Okada (1985). Its crest and trough amplitudes are $+3.9 \mathrm{~m}$ and $-1.8 \mathrm{~m}$, respectively (see Fig. 2). The depression of the water surface is assumed to be at the south (at the deepest part of the trench). 

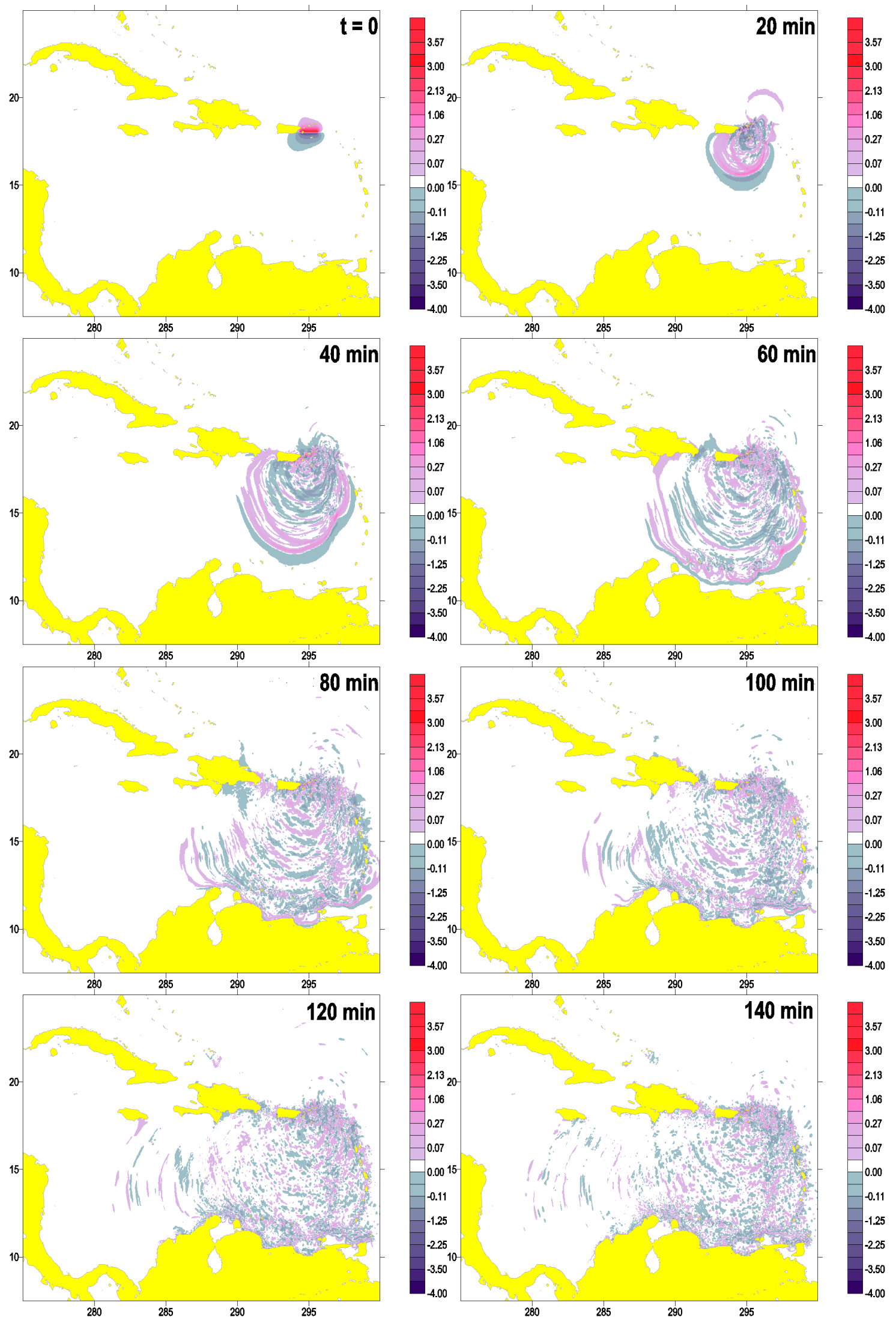

Fig. 2. Snapshots of the tsunami wave propagation for various times with 20 minute intervals (The horizontal and vertical axes are western longitude and northern latitude, respectively. The water surface elevation is in meters). 


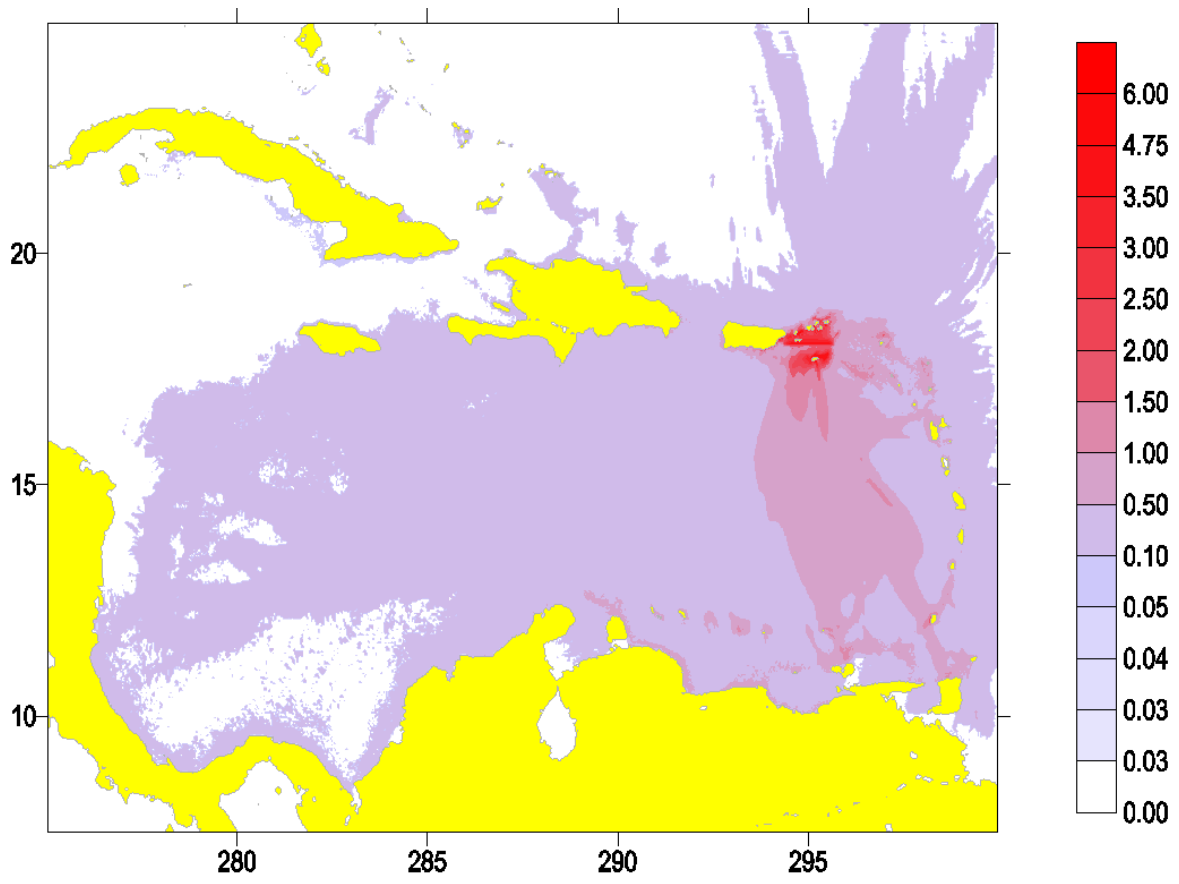

Fig. 3. The (directivity diagram of tsunami propagation) distribution of computed maximum positive tsunami amplitudes (The horizontal and vertical axes are western longitude and northern latitude, respectively. The water surface elevation is in meters).

\section{Computed Characteristics of Tsunami Waves in the Caribbean Sea}

For modelling of the 1867 event, we have used the propagation model and computed the sea state at different time steps, time histories of water surface oscillations and the maximum positive amplitudes at every grid point. Snapshots of the tsunami wave propagation are shown in Fig. 2. Tsunami waves affected all islands of the Lesser Antilles for about one hour. Previous calculations of the tsunami travel time for the tsunami generated at Charlotte Amalie (US Virgin Islands) give about $1.5 \mathrm{~h}$ (Weissert, 1990), but in his case the source centre is farther than the tsunami source considered here, in the centre of Anegada Passage. After two hours, there is a complicated picture of tsunami waves in the Lesser Antilles after reflection and diffraction on islands and shelf zone.

Figure 3 shows the distributions of the computed maximum elevations of the sea level (tsunami directivity). The waves are significant in the epicentral area: the Virgin Islands and Puerto Rico. The tsunami propagates mainly in a southerthly direction (Grenada, Trinidad and Isla de Margarita) and eastward (Saba, St. Kitts, Antigua and, particularly, northern Guadeloupe). The central part of the Lesser Antilles (Dominica, Martinique and St. Lucia) is weakly affected by the tsunami waves. According to the observations (Table 1), the tsunami was significant at many islands of the Lesser Antilles (except its central part) and, of course, in Puerto Rico and the Virgin Islands. Therefore, the theoretical model predicts correctly the main directions of tsunami propagation in the vicinity of the Lesser Antilles. The numerical results also show the "finger" structure of the wave paths to the Atlantics (north-east-north), but there is no tsunami observational data north of the Great Antilles.

Computed tsunami records at several locations in the epicentral area (Virgin Islands, Puerto Rico) are shown in Fig. 4. The crest amplitudes here are high, up to $6 \mathrm{~m}$, and the trough depth exceeds $6 \mathrm{~m}$. Unfortunately, the resolution of the bathymetry used in the coastal zone was not good enough $(3 \mathrm{~km})$, and the computed records cannot exactly correspond to the "real" records in the coastal bays and to the eyewitness reports. But roughly, they should describe the observed features of the tsunami. For instance, according to the observations, there are two giant waves generated by two shocks in the Virgin Islands and Puerto Rico with the time interval of $10 \mathrm{~min}$. It was also observed at most of the locations that the sea receded first. Our simulation considers the coseismic generation of the wave by a single shock. Thus a single large wave in the epicentral zone is selected as the input for the simulation. The computed tsunami records at Frederiksted (St. Croix, Virgin Islands) (Fig. 4) definitely show a huge wave up to $6 \mathrm{~m}$ arriving after a depression of $1-2 \mathrm{~m}$, in good agreement with the observations. For Christiansted (St. Croix), the simulations predict two large waves of $3 \mathrm{~m}$ coming after a depression of $1 \mathrm{~m}$. To south-east from Puerto Rico (Yacoboa and Arroyo) the tsunami began also with the sea receding. But the same features are not obtained for other places. In Cruz Bay (St. John) the tsunami began with a rise up to $3 \mathrm{~m}$ and the second wave arrived after a deep depression of $6 \mathrm{~m}$. The elevation north of the source in our calculations corresponds to the seismic source model (elevation in northern part). Perhaps the earthquake initiated the landslide; in 
Table 2. Computed tsunami amplitudes near the Caribbean Islands during the 1867 event

\begin{tabular}{|c|c|c|c|c|c|}
\hline \multirow[t]{2}{*}{ Location } & \multicolumn{2}{|c|}{ Coordinates } & \multirow[t]{2}{*}{ Water depth(m) } & \multicolumn{2}{|c|}{ Amplitudes (m) } \\
\hline & ${ }^{\circ} \mathrm{W}$ & ${ }^{\circ} \mathrm{N}$ & & positive & negative \\
\hline Guayama, Puerto Rico & 66.028 & 17.970 & 23.5 & 3.9 & 5.1 \\
\hline Yabucoa, Puerto Rico & 65.844 & 18.036 & 65.1 & 2.5 & 3.0 \\
\hline San Juan, Puerto Rico & 65.906 & 18.398 & 26.8 & 0.5 & 0.5 \\
\hline Vieques, Puerto Rico & 65.17 & 18.135 & 18.1 & 3.0 & 4.5 \\
\hline Charlotte Amalie, St Thomas, Virgin Islands & 64.924 & 18.365 & 59.8 & 2.9 & 5.1 \\
\hline Road Town, Tortola, Virgin Is. & 64.587 & 18.497 & 77.4 & 2.5 & 4.4 \\
\hline Cruz Bay, St John, Virgin Is. 64.702 & 18.332 & 22.8 & 5.7 & 7.5 & \\
\hline Christensted, St. Croix, Virgin Islands & 64.71 & 17.739 & 27.2 & 3.8 & 3.0 \\
\hline Fredericksted, St. Croix, Virgin Islands & 64.894 & 17.74 & 74.9 & 6.0 & 2.8 \\
\hline St. John's, Antigua & 61.857 & 17.081 & 9.2 & 0.8 & 0.8 \\
\hline St. Rose, Guadeloupe & 61.735 & 16.39 & 26.9 & 0.9 & 0.8 \\
\hline Deshaies, Guadeloupe & 61.827 & 16.291 & 21.3 & 0.8 & 0.8 \\
\hline Basse-Terre, Guadeloupe & 61.765 & 16.028 & 42.9 & 0.6 & 0.8 \\
\hline Pointe-a-Pitre, Guadeloupe & 61.489 & 16.225 & 67.1 & 0.4 & 0.6 \\
\hline Roseau, Dominica & 61.428 & 15.237 & 48.2 & 0.4 & 0.4 \\
\hline Fort-de-France, Martinique & 61.09 & 14.579 & 34.3 & 0.7 & 0.7 \\
\hline Kingstown, St Vincent & 61.275 & 13.229 & 28.8 & 0.7 & 1.0 \\
\hline Gouyave, Grenada & 61.704 & 12.208 & 28.5 & 1.4 & 1.5 \\
\hline Saint George's, Grenada & 61.765 & 12.109 & 15.9 & 2.3 & 2.8 \\
\hline Port-of-Spain, Trinidad & 61.459 & 10.792 & 9.3 & 1.2 & 0.8 \\
\hline Isla de Margarita & 63.943 & 11.221 & 8.5 & 0.9 & 1 \\
\hline Curmana, Venezuela & 64.188 & 10.430 & 18.8 & 0.9 & 0.6 \\
\hline Barcelona, Venezuela & 64.863 & 10.101 & 8.8 & 0.8 & 0.7 \\
\hline Caracas, Venezuela & 67.47 & 10.529 & 8.4 & 0.4 & 0.5 \\
\hline Puerto Cabello, Venezuela & 68.083 & 10.529 & 25.4 & 0.6 & 0.6 \\
\hline Bonaire, Netherlands Antilles & 68.85 & 12.11 & 26.5 & 0.1 & 0.1 \\
\hline Cartagena, Colombia & 75.475 & 10.661 & 48.9 & 0.5 & 0.4 \\
\hline Puerto Cabezas, Nicaragua & 83.296 & 14.052 & 8.4 & 0.2 & 0.2 \\
\hline Port-au-Prince, Haiti & 72.408 & 18.596 & 6.0 & 0.3 & 0.3 \\
\hline Cayes, Haiti & 73.758 & 18.168 & 27 & 0.3 & 0.3 \\
\hline Barahona, Dominican Republic & 71.058 & 18.168 & 77.1 & 0.4 & 0.3 \\
\hline Santa Domingo, Dominican Republic & 69.77 & 18.461 & 44.5 & 0.4 & 0.3 \\
\hline La Romana, Dominican Republic & 68.912 & 18.398 & 24.2 & 0.9 & 0.8 \\
\hline
\end{tabular}

this case the depression of the wave is at the shore side, and this can explain the observed sea recession on St. Thomas, St. John and Tortola. We would like to mention that the result (mainly, the number of large waves and their amplitudes) is very sensitive to the location of the selected sites and the reproduction of the coastal line of these relative small islands (about 10 grid points).

Figure 5 demonstrates the computed records for several locations at the Lesser Antilles. Computed amplitudes in the northern and central parts are less than $1 \mathrm{~m}$, meanwhile they exceed $2 \mathrm{~m}$ in the southern part, in particular, in Grenada. The tsunami approaches the Lesser Antilles 40-60 min after the earthquake, and this is in agreement with the observations. Trinidad is located in the shallowest zone, and as a result, the wave approaches its coast in 2 hrs. At all coastal locations at the Lesser Antilles the initial wave has been observed as a recession of the sea, which confirms the theoretical predictions. In most locations, the crest amplitude of the next (positive) wave is maximum compared to the following waves. Such a wave is evident on the computed records for Antigua and Grenada.
On the northern part of Guadeloupe (Deshaies, St. Rose), computed amplitudes are less than $1 \mathrm{~m}$. They are significantly less than the observations $(18 \mathrm{~m})$ and the corrected value (10 m) at Deshaies (Zahibo and Pelinovsky, 2001). The accuracy of the runup value calculated by the finite difference technique is limited by the grid size. When the grid size is larger than the inundation distance, the model calculates the maximum positive tsunami amplitudes near the coast. Hence, we assume that one of the main reasons for the discrepancy between computed and observed tsunami wave heights is a rather coarse grid size $(3000 \mathrm{~m})$, which was used in the present simulation. The other reason might be the focusing of the wave energy towards Deshaies and St. Rose according to local amplification by refraction and reflection processes. Results of our calculations also show the appearance of a group of tsunami waves, and this may be related to the resonance effects between various islands, as well to the tsunami propagation in the form of edge waves along the Lesser Antilles. Significant oscillations of the sea level can continue one hour or more, in agreement with the observations. As pointed out by witness reports, "the whole event 

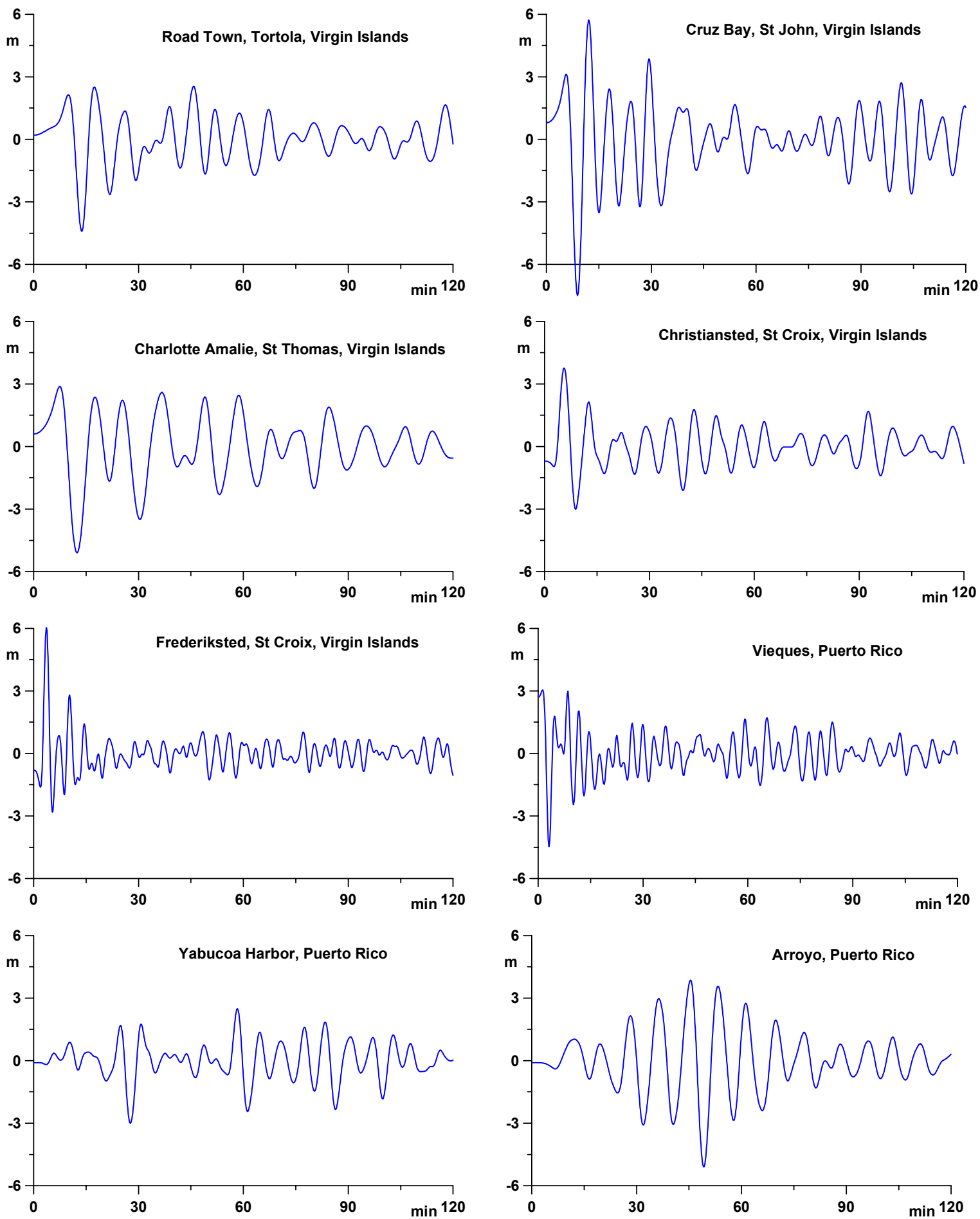

Fig. 4. Computed time histories of water surface elevations at several coastal locations in the epicentral zone (horizontal axis is the time and vertical axis is water surface elevation).

lasted for above 40 min" at the Grenadines, and there were 6 waves at Grenada (Reid and Taber, 1920). So, qualitatively, the computed results are in reasonable agreement with the data of observations except for the northern part of Guadeloupe.
More detailed information about the computed waves is summarised in Table 2. We give the geographical coordinates with high accuracy for each selected site. The name of the nearest location of the selected point is also indicated in Table 2. Since the computed amplitudes at selected locations are dependent on the water depth at those locations, we 

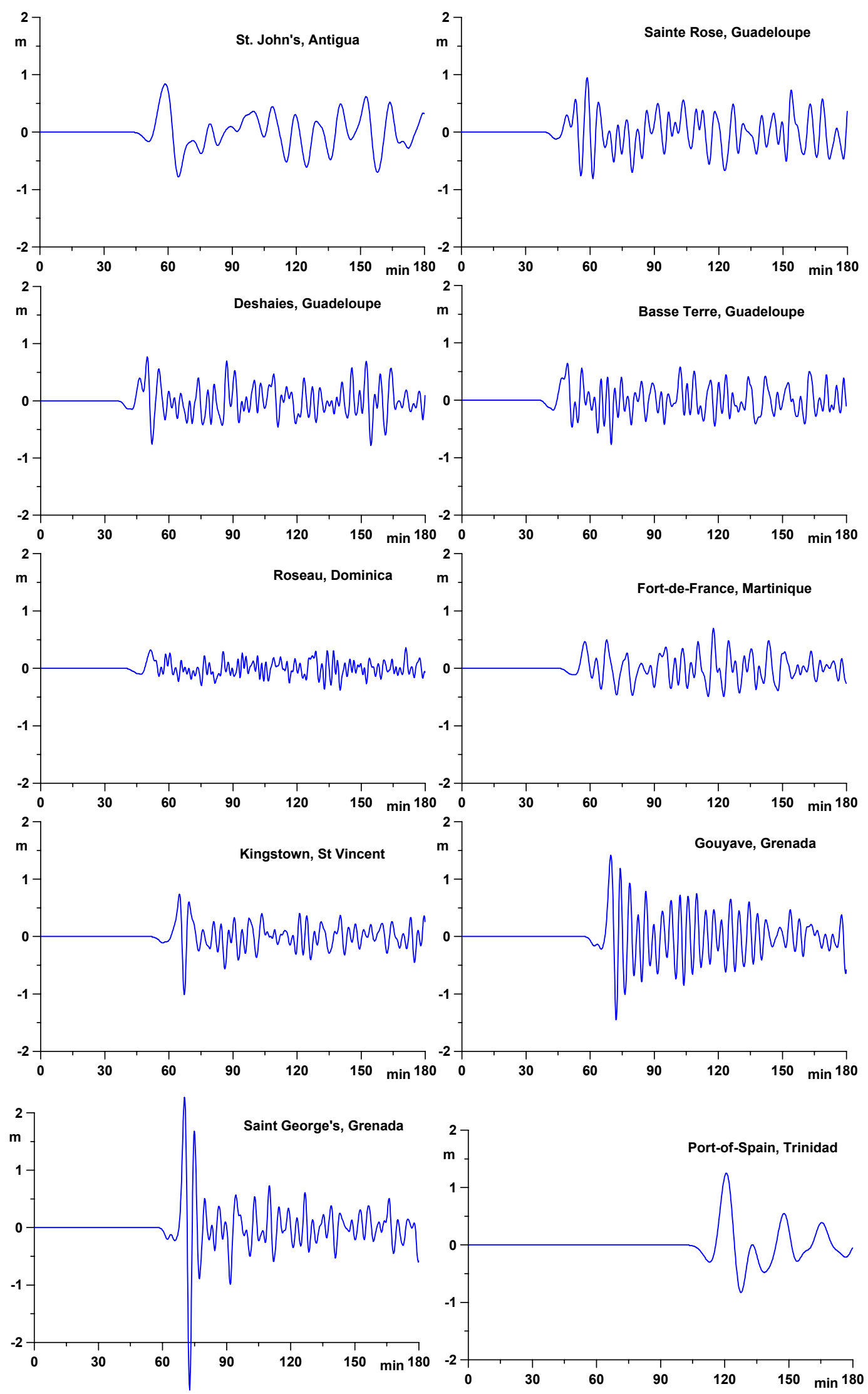

Fig. 5. Computed time histories of water surface elevations at several coastal locations in the Lesser Antilles (horizontal axis is the time and vertical axis is water surface elevation). 


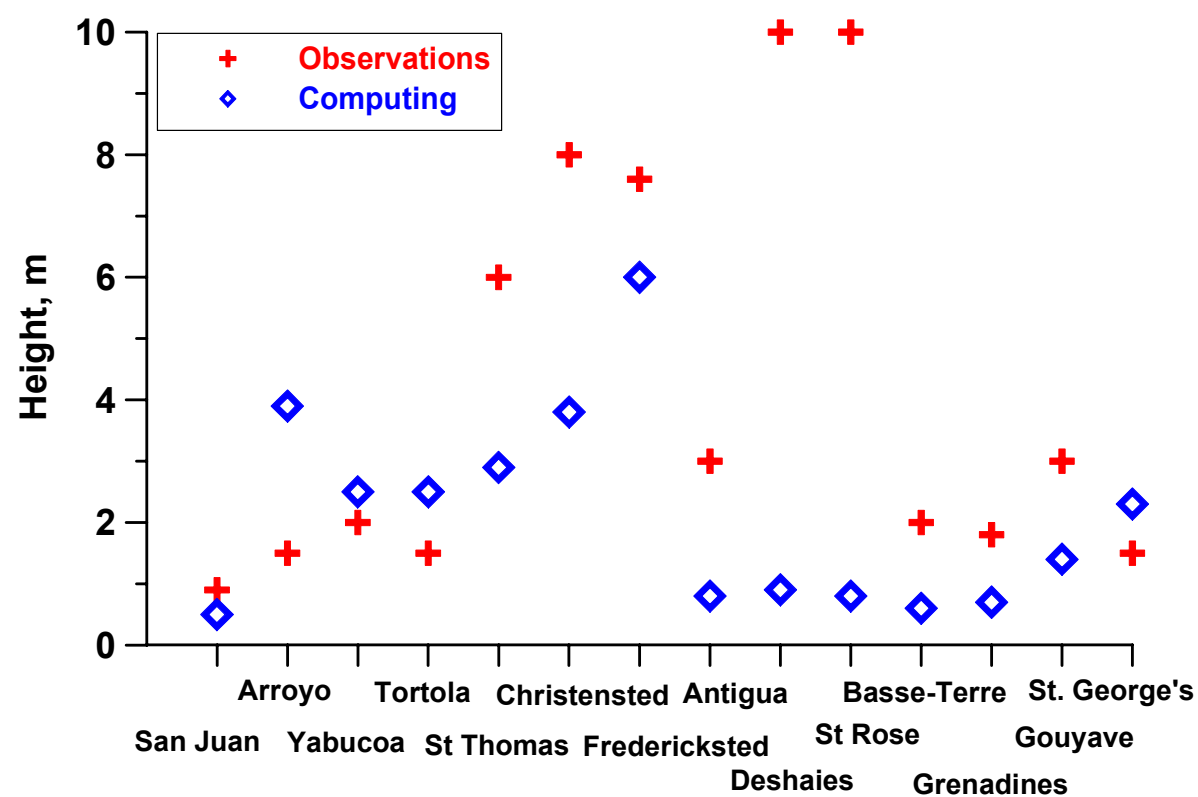

Fig. 6. Comparison of computed and observed positive amplitudes.

also show the water depth for each location in Table 2. Calculated maximum positive and negative elevations are given in Table 2. According to the calculations, the amplitude of the 1867 tsunami exceeds $10 \mathrm{~cm}$ in most of the countries of the Caribbean Sea (Puerto Rico, Dominican Republic, Haiti, Cuba, Nicaragua, Colombia, Venezuela, Lesser Antilles and Virgin Islands). Since amplitudes of $10-50 \mathrm{~cm}$ for long waves are difficult to detect by eye, the number of reliable observations in 1867 could not be high. Computed amplitudes exceeding $1 \mathrm{~m}$ are obtained for the Virgin and Lesser Antilles islands, and Puerto Rico, where tsunami waves were observed clearly. Therefore, the numerical results on average are in good agreement with the observations.

Comparison of the observed data with computational results is shown in Fig. 6. All observation sites west of the source (Puerto Rico) to the southern Lesser Antilles through the Virgin Islands are shown in axis $x$ (locations of these points are presented in Fig. 1). The observed wave heights of $10 \mathrm{~m}$ in Deshaies and St. Rose (Guadeloupe) are in evident contrast with computed amplitudes. Earlier, a height of $18 \mathrm{~m}$ was cited for these locations in Guadeloupe (Devill, 1867; Reid and Taber, 1920; Lander et al., 2002). After an inspection of these places and investigation of historical materials, Zahibo and Pelinovsky (2001) suggested that the tsunami waves could not exceed $10 \mathrm{~m}$. Perhaps, the wave height really was significantly less, about $5 \mathrm{~m}$; such waves can induce the damage described in literature ("wave broke over the shore and carried off all floatable objects"), but it has not been confirmed. If a height of $5 \mathrm{~m}$ is assumed for these locations, the correlation between observations and computing will be more evident. Just now it is impossible to state: were $10 \mathrm{~m}$ waves really observed due to a very local effect, or this is an exaggeration? So we will still use $10 \mathrm{~m}$ as the observed height. Computed wave heights are maximum near the epicentre area and also in the southern Lesser Antilles, in reasonable agreement with observations. It is important to mention that tsunami waves are localized mainly in the Caribbean Sea, and the penetration of tsunami waves into the Atlantic through the Lesser Antilles straits and passages as well through the Virgin Island passages is relatively weak. The explanation is evident: tsunami waves effectively reflect and refract from the deepest Puerto Rico Trench behind the Caribbean Islands. As a result, the tsunami energy will mainly disperse in the Caribbean Sea.

\section{Conclusions}

The 1867 tsunami in the Virgin Islands was recorded in many islands of the Caribbean Basin, in particular in Puerto Rico, Virgin Islands (St. Thomas, St. Croix, Tortola, Peter Is.) and the Lesser Antilles (Saba, St. Kitts, Antigua, Guadeloupe, Grenadines, Grenada). Observations of this tsunami are compared with the results of the numerical simulation. The mathematical model applied for the tsunami analysis is based on nonlinear long water theory in Cartesian coordinates. The bathymetry used is obtained from ETOPO2 with spatial resolution $3 \mathrm{~km}$. The results of the numerical simulation show that the directivity diagram has peaks in the direction of the southern Lesser Antilles (Grenada) and these peaks are confirmed by the observations. The observed form of the tsunami wave trains in different locations in the Caribbean Sea is generally confirmed by the computed results. The distribution function of tsunami crest amplitude along the coast is in reasonable agreement with the observations if the recorded $10 \mathrm{~m}$ heights of tsunami waves in the northern part of Guadeloupe (Deshaies and St. Rose) are ignored. This huge value of tsunami height $(10 \mathrm{~m})$ recorded 
in the Caribbean Sea seems to be an exaggeration, or to be related with a very local amplification of the wave.

Acknowledgements. We would like to thank Professor Fumihiko Imamura for developing and providing the numerical code of TUNAMI N2 by Tsunami Inundation Modeling Exchange (TIME) program. We also thank Prof. Alexander Rabinovich for his kind guidance and help during the preparation of this paper, and Dr. Henry Falconer for editing of the manuscript. Authors acknowledge the grants from EGIDE $(04500 \mathrm{YH})$, and INTAS (01-2156). Russian co-authors have the particular support from RFBR (02-05-65107). The grant by TUBITAK with project no YDABCAG-60 is also acknowledged. Efim Pelinovsky acknowledges the support from the Université des Antilles et de la Guyane.

\section{References}

Deplus, C., Le Friant, A., Boudon, G., Komorowski J.-C., Villemant, B., Harford, C., Segoufin, J., and Cheminee, J.-L.: Submarine evidence for large-scale debris avalanches in the Lesser Antilles Arc, Earth and Planetary Science Letters, 192, 2, 145157, 2001.

Devill, S-C.: Sur le tremblement de terre du 18 novembre 1867 aux Antilles, Comptes Rendus Acad. Sci. Paris, 65, 1110-1114, 1867.

Doganay, C.: The Propagation of Long Waves in Iskenderun Bay, Ms.Sc. Thesis, Middle East Technical University, Civil Engineering Department, Ocean Engineering Research Center, (supervisor: A. C.Yalciner), 1997.

ETDB/ATL: Expert Tsunami Database for the Atlantics, Version 3.6 of March 15, 2002. Tsunami Laboratory, Novosibirsk, Russia, 2002.

Fujima, K., Masamura, K., and Goto, C.: Theoretical examinations of long-wave damping by sea bottom friction. Coastal Engineering Journal, 44, 3, 217-245, 2002.

Goto, C., Ogawa, Y., Shuto, N., and Imamura, N.: Numerical method of tsunami simulation with the leap-frog scheme (IUGG/IOC Time Project), IOC Manual, UNESCO, No. 35, 1997.

Heinrich, F., Mangeney, A., Guibourg, S., and Roche, R.: Simulation of water waves generated by a potential debris avalanche in Montserrat, Lesser Antilles, Geophys. Res. Lett., 25, 9, $3697-$ 3700, 1998 .

Heinrich, F., Guibourg, S., Mangeney, A., and Roche, R.: Numer- ical modelling of a landslide-generated tsunami following a potential explosion of the Montserrat Volcano, Phys. Chem. Earth (A), 24, 2, 163-168, 1999a.

Heinrich, F., Roche, R., Mangeney, A., and Boudon, G.: Modeliser un raz de maree cree par un volcan, La Recherche, 318, 67-71, 1999b.

Heinrich, F., Boudon, G., Komorowski, J. C., Sparks, R. S. J., Herd, R., and Voight, B.: Numerical simulation of the December 1997 debris avalanche in Montserrat. Geophys. Res. Lett., 28, 13, 2529-2532, 2001.

Hooper, D. M. and Mattioli, G. S.: Kinematic modelling of pyrolastic flows produced by gravitational dome collapse at Soufriere Hills. Natural Hazards, 23, 65-86, 2001.

Imamura, F.: Review of tsunami simulation with finite difference method, in: Long Wave Runup Models, edited by Liu, F., Synolakis, C., and Yeh, H., World Scientific, 1996, 25-42.

Lander, J. F., Whiteside, L. S., and Lockridge, P. A.: A brief history of tsunami in the Caribbean Sea, Science of Tsunami Hazards, 20, 2, 57-94, 2002.

Le Friant, A.: Les déstabilisations de flanc des volcans actifs de l'arc des Petites Antilles: origines et conséquences, These de Doctorat, Université de Paris VII, 377p, 2001.

Mader, C. L.: Modeling the 1755 Lisbon tsunami, Science of Tsunami Hazards, 19, 2, 93-98, 2001a.

Mader, C. L.: Modeling the La Palma landslide tsunami, Science of Tsunami Hazards, 19, 3, 150-170, 2001b.

Mercado, A. and McCann, W.: Numerical simulation of the 1918 Puerto Rico tsunami, Natural Hazards, 18, 1, 57-76, 1998.

Okada, Y.: Surface deformation due to shear and tensile faults in a half-space, Bull. Seism. Soc. America, 75, 1135-1154, 1985.

Pararas-Carayannis, G.: Evaluation of the threat of mega tsunami generation from postulated massive slope failures of island stratovolcanoes on La Palma, Canary Islands, and on the Island of Hawaii, Science of Tsunami Hazards, 20, 5, 251-277, 2002.

Reid, H. F. and Taber, S.: The Virgin Islands Earthquakes of 18671868, Bull. Seismol. Soc. America, 10, 9-30, 1920.

Weissert, T. P.: Tsunami travel time charts for the Caribbean, Science of Tsunami Hazards, 8, 2, 67-78, 1990.

Yalciner, A. C., Alpar, B., Altinok, T., Ozbay, I., and Imamura, F.: Tsunamis in the Sea of Marmara, Historical documents for the past, models for the future, Marine Geology, 190, 1-2, 445-463, 2002.

Zahibo, N. and Pelinovsky, E.: Evaluation of tsunami risk in the Lesser Antilles, Natural Hazard and Earth Sciences, 3, 221-231, 2001. 